\title{
Rumen fermentation pattern of dairy heifers fed restricted amounts of low, medium, and high concentrate diets without and with yeast culture
}

\author{
G.J. Lascano, A.J. Heinrichs
}

\begin{abstract}
A B S T R A C T
Restricted feeding and high concentrate diets are potential strategies for growing dairy heifers. Ruminal manipulation with additives such as Saccharomyces cerevisiae yeast culture (YC) has been shown to alter digestibility when added to this type of diet. An experiment was conducted to investigate the ruminal fermentation and in situ digestibility of diets with 3 different levels of forage to concentrate $(\mathrm{F}: \mathrm{C})$ fed at restricted intake without and with YC addition. Three cannulated post-pubertal Holstein heifers (age 18.0 \pm 1.2 months; body weight 449.6 $\pm 19.7 \mathrm{~kg}$ ) were fed diets consisting of corn silage as the sole forage source in a 3 period (35-day) Latin square design. Heifers were fed diets for 21 days with no YC addition, followed by 14 days where YC was added to the diet (1 $\mathrm{g} / \mathrm{kg}$ as fed basis). Low (LC), medium (MC), and high (HC) concentrate diets (20,40, and $60 \%$ concentrate) were fed once daily on a restricted basis to provide $0.22 \mathrm{Mcal} \mathrm{ME} / \mathrm{kg}$ empty BW $\mathrm{BW}^{0.75}$. Rumen fluid was sampled on days 18 and 32 of each period, and rumen contents were evacuated on days 21 and 35 of each period. An in situ study was done on days 14 to 17 and on days 28 to 31 . Mean ruminal pH was not different between dietary treatments and no YC effect was detected. Mean total volatile fatty acids (VFA) and ruminal ammonia-nitrogen $\left(\mathrm{NH}_{3}-\mathrm{N}\right)$ concentration was also not different among diets with different F:C. Molar proportions of acetate were decreased, and propionate were increased; while the acetate-to-propionate ratio was decreased as the concentrate level increased from LC to HC. Total VFA, propionate, and acetate as well as isoacids concentration increased, yet $\mathrm{NH}_{3}-\mathrm{N}$ concentration decreased with YC addition in all diets. From these results we conclude that feeding $\mathrm{HC}$ diets in restricted amounts had minimal effects on rumen fermentation rate between different F:C diets. The addition of $\mathrm{YC}$ modified $\mathrm{NH}_{3}-\mathrm{N}$ and volatile fatty acid concentrations in the rumen in all 3 diets in this study, presumably through alterations in endproduct production and utilization.
\end{abstract}

\section{Introduction}

One of the most useful measures of animal performance across species is feed efficiency, a direct marker of the animal's ability to be more productive. Improving the efficiency to convert units of feed to units of growth means less feed is required to raise more livestock in a given amount of time (Loerch, 1990; Hoffman et al., 2007). Another marker of animal performance is average daily gain (ADG; Gerrard and Grant, 2003). Research suggests that a prepubertal ADG of approximately $800 \mathrm{~g} / \mathrm{d}$ is appropriate for large breed dairy heifers to maximize first lactation milk yields (Zanton and Heinrichs, 2005). Adequate body size is also necessary, and an age at first calving between 23 and 24 months results in profitable milk production (Pirlo et al., 2000). Since feed costs contribute the most to raising heifers, it is logical to expect that improving feed efficiency could decrease the cost for raising dairy heifers, provided ADG is adequate.

A typical dairy heifer is fed a ration primarily derived from forages as opposed to concentrates. However, there is a large inefficiency associated with this method of feeding due to lower digestibility of most forages, greater metabolic protein 
and energy requirements associated with digesting forage (Reynolds et al., 1991), and higher feed costs per unit of energy as compared to concentrates (Zanton and Heinrichs, 2007). The potential therefore exists to replace a significant proportion of the ration forage dry matter (DM) with concentrate DM, reducing some inefficiency associated with raising dairy heifers while maintaining ADG. Experiments have recently been conducted to evaluate heifer growth characteristics and nutrient utilization when fed differing forage to concentrate ratios $(\mathrm{F}: \mathrm{C})$ at restricted intakes to achieve similar ADG (Hoffman et al., 2007; Zanton and Heinrichs, 2007). In areas with limited land resources, corn silage is often the forage of choice due to its high DM yield potential per hectare. However, when limit-feeding high energy forages and diets based on corn silage, rumen fermentation and growth of the animal may be challenged.

Yeast culture (YC) has been used as an additive to ruminant diets since 1924, with various results reported in the literature. Results following addition of YC based on Saccharomyces cerevisiae to the diet include improved productivity in both lactating and growing animals. Though increases in productivity are generally variable, rumen fermentation rate and patterns seem to be involved in this response (Carro et al., 1992). The mode of action of YC products has not been completely described, but many hypotheses are related to changes in rumen fermentation rate and patterns. Volatile fatty acid (VFA) production, neutral detergent fiber (NDF) digestibility and disappearance, organic matter digestibility, and bacterial and protozoal populations have been enhanced by yeast supplementation (Lascano and Heinrichs, 2007). Decreases in lactic acid concentration and the lag time of DM degradation as well as stabilization of rumen $\mathrm{pH}$ are other observed effects (Wallace, 1996). Overall, the rumen environment typically benefits, which leads to an improved metabolic performance of the animal.

Research indicates that including live or dead YC products in adult and young ruminant diets can alter the rumen environment; however, different responses have been found depending on the diet used (Lascano and Heinrichs, 2007). In lactating dairy cows, YC has been shown to increase the nutritional value of high concentrate diets (Arambel and Kent, 1990). Therefore, the purpose of this study was to investigate the effect of YC in the rumen environment when added to limit-fed, high concentrate diets based on corn silage offered to dairy heifers.

\section{Materials and methods}

\subsection{Animal, housing and diet}

Three Holstein dairy heifers, each previously fitted with a $10.6 \mathrm{~cm}$ rumen cannula (Bar Diamond, Parma, ID,USA) under anesthesia, were housed in a mechanically ventilated and environmentally controlled tie stall barn. Animal care procedures followed the Pennsylvania State University Institutional Animal Care and Use Committee approval. Total mixed rations (TMR) contained corn silage as the sole forage source, ground corn, soybean meal and heat treated soybean meal (Table 1). Animals were fed once daily at $1000 \mathrm{~h}$ and no refusals were observed during the trial. Rations were mixed daily in a rotary mixer (Calan Super Data Ranger; American
Calan, Northwood, NH, USA) for approximately 5 min. Three $\mathrm{F}: \mathrm{C}$ were formulated and mixed to provide $80: 20,60: 40$, and 40:60, designated low (LC), medium (MC), and high (HC) concentrate, respectively. Yeast culture product (YC, YeaSacc $^{\circledR} 1026$, Alltech, Inc., Nicholasville, KY, USA) was added at a rate of $1 \mathrm{~g} / \mathrm{kg} / \mathrm{d}$ as fed basis. This dose was selected to have a constant inclusion level of YC across treatments with different intakes. Research shows that when the amount of YC is constant regardless of the intake, the YC effect in animals with higher feed consumption tends to disappear (Lascano and Heinrichs, 2007; Robinson and Erasmus, 2007). Feed ingredients and TMR samples were collected daily and composited for every period, dried in a forced air oven $\left(55{ }^{\circ} \mathrm{C}\right.$ ) immediately after collection, and stored for further analysis. Health conditions of experimental animals were monitored twice daily at 0830 and $2030 \mathrm{~h}$. Heifers had free choice access to water and were released $1 \mathrm{~h}$ post-feeding for approximately $1 \mathrm{~h}$ daily to a paved exercise lot, except on intensive sampling days. Heifers were kept for $30 \mathrm{~d}$ before starting the experiment to adapt to the tie stall facility and experimental diets. Animals at $18.0 \pm 1.2$ months of age with 449.6 $\pm 19.7 \mathrm{~kg}$ body weight (BW) were randomly assigned to 1 of 3 treatments in a $3 \times 3$ Latin square design. Each of the 3

Table 1

Ingredient and nutrient composition of high concentrate (HC), medium concentrate (MC), and low concentrate (LC) rations fed to heifers.

\begin{tabular}{|c|c|c|c|c|}
\hline \multirow[b]{2}{*}{ Composition } & \multicolumn{4}{|c|}{ Treatment } \\
\hline & LC & MC & $\mathrm{HC}$ & SE \\
\hline \multicolumn{5}{|l|}{ Ingredients (\%DM) } \\
\hline Corn silage $^{1}$ & 80.00 & 60.00 & 40.00 & . \\
\hline Ground corn & 5.67 & 29.60 & 47.70 & . \\
\hline Soybean meal (SBM) & 9.47 & 9.94 & 9.00 & . \\
\hline Heat treated SBM & 1.60 & 0.80 & 0.00 & . \\
\hline Sodium bicarbonate & 0.35 & 0.35 & 0.35 & . \\
\hline High mineral mix $^{2}$ & 0.00 & 1.23 & 2.95 & . \\
\hline Low mineral $\mathrm{mix}^{3}$ & 2.45 & 1.48 & 0.00 & . \\
\hline \multicolumn{5}{|l|}{ Nutrients ${ }^{4}$} \\
\hline $\mathrm{DM} \%$ & $41.93^{\mathrm{a}}$ & $50.61^{\mathrm{b}}$ & $56.51^{\mathrm{c}}$ & 1.03 \\
\hline $\mathrm{CP} \%$ & $12.93^{\mathrm{b}}$ & $12.38^{\mathrm{a}}$ & $13.17^{\mathrm{b}}$ & 0.10 \\
\hline Soluble, \% of CP & $43.65^{b}$ & $43.65^{b}$ & $33.84^{\mathrm{a}}$ & 0.76 \\
\hline $\mathrm{ADF} \%$ & $20.45^{c}$ & $17.93^{\mathrm{b}}$ & $12.97^{\mathrm{a}}$ & 0.19 \\
\hline NDF $\%$ & $34.18^{c}$ & $30.03^{b}$ & $23.23^{\mathrm{a}}$ & 0.38 \\
\hline NFC $\%^{5}$ & $48.05^{\mathrm{a}}$ & $53.30^{\mathrm{b}}$ & $58.48^{c}$ & 0.14 \\
\hline TDN $\%^{6}$ & $72.13^{\mathrm{a}}$ & $75.13^{b}$ & $78.63^{a}$ & 0.11 \\
\hline $\mathrm{ME}, \mathrm{Mcal} / \mathrm{kg} \mathrm{DM}^{7}$ & $2.63^{\mathrm{a}}$ & $2.72^{\mathrm{b}}$ & $2.84^{\mathrm{c}}$ & 0.01 \\
\hline Ca \% & 0.38 & 0.37 & 0.36 & 0.02 \\
\hline P \% & 0.30 & 0.28 & 0.30 & 0.01 \\
\hline $\mathrm{Mg} \%$ & 0.20 & 0.22 & 0.23 & 0.01 \\
\hline K \% & $1.33^{c}$ & $1.12^{\mathrm{b}}$ & $1.02^{\mathrm{a}}$ & 0.03 \\
\hline
\end{tabular}

a,b,c Means in the same row with different superscripts differ $(P<0.05)$.

${ }^{1}$ Corn silage contained: 33.7\% DM, 38.4\% NDF, 23.9\% ADF, 9.1\% CP, 36.32\% starch on DM basis.

${ }^{2}$ High mineral mix contained: 7.8\% vitamin E, 2.6\% vitamin ADE, 28.6\% distillers corn with soluble vitamin $\mathrm{D}, 14.6 \%$ plain salt, $36.5 \%$ limestone, $2.6 \%$ magnesium oxide, $5.7 \%$ trace mineral premix, and $1.6 \%$ selenium premix on a DM basis.

${ }^{3}$ Low mineral mix contained: $7.4 \%$ vitamin E, $2.5 \%$ vitamin ADE, $28.6 \%$ distillers corn with soluble vitamin D, 13.9\% plain salt, 34.8\% limestone, $6.0 \%$ magnesium oxide, $5.5 \%$ trace mineral premix, and $1.5 \%$ selenium premix on a DM basis.

${ }^{4} n=6$ composite samples representing 42 samples per treatment taken daily throughout the collection periods.

${ }^{5}$ Non fibrous carbohydrates analyzed by Cumberland Valley Analytical Services Laboratory (Maugansville, MD, USA).

${ }^{6}$ Total digestible nutrients (calculated from ingredients).

${ }^{7}$ Estimated: metabolizable energy $(\mathrm{ME})=\mathrm{TDN} \times 0.04409 \times 0.82$ (Lammers and Heinrichs, 2000). 
periods consisted of 35 days. Heifers were fed treatment diets for 21 days with no YC addition (14 days of adaptation and 7 days of sampling period), followed by 14 days with YC addition in which 7 days were allowed for adaptation to YC and 7 days of sampling period.

Dry matter offered ( $\mathrm{g} / \mathrm{kg} \mathrm{BW}$ ) was determined using NRC (2001) and formulated to provide $800 \mathrm{~g} / \mathrm{d}$ ADG (restrictively to attain $0.22 \mathrm{Mcal} \mathrm{ME}$ intake $/ \mathrm{kg}^{\mathrm{EBW}}{ }^{0.75}$ ). Measured BW determined the quantity of TMR received for the following 7 days; however, DM intake was not changed immediately prior to sampling, as that could have increased variation in the results. Diets were formulated to provide 2.60, 2.73 and $2.82 \mathrm{Mcal}$ of metabolizable energy (ME)/ $\mathrm{kg}$ DM for LC, MC, and $\mathrm{HC}$ respectively, with a fixed level of $13 \%$ crude protein (CP; Table 1), and similar daily intakes of $\mathrm{CP}$, energy, minerals and vitamins (Table 2).

\subsection{Feed nutrient composition}

Feed ingredients and TMR were ground through a 1-mm screen using a Wiley Mill (Arthur H. Thomas, Philadelphia, PA, USA) and analyzed for DM, organic matter, ash (AOAC, 1990), acid detergent fiber, and NDF (Van Soest et al., 1991) using an ANKOM $^{200}$ Fiber Analyzer (ANKOM Technology Corporation, Fairport, NY, USA) with heat treated $\alpha$-amylase and sodium sulfite utilized in the NDF procedure. Crude protein (AOAC, 1990) was analyzed using a Leco FP-528 Nitrogen Combustion Analyzer (Leco, St. Joseph, MI, USA), Non fibrous carbohydrates (NFC), macro and micro minerals were analyzed by the Cumberland Valley Analytical Services Laboratory (Maugansville, MD, USA). Metabolizable energy was calculated using the equation: $\mathrm{TDN} \times 0.04409 \times 0.82$ (Lammers and Heinrichs, 2000). Heifers were weighed weekly, with 2 measurements at 0800 and 1800 h, 2 h prior and $8 \mathrm{~h}$ after feeding, except the week immediately prior to intensive sampling.

Table 2

Effect of feeding different levels of forage to concentrate to replacement heifers on nutrient and energy intake.

\begin{tabular}{|c|c|c|c|c|c|}
\hline & \multicolumn{5}{|c|}{ Treatment $^{1}$} \\
\hline & LC & MC & $\mathrm{HC}$ & SE & $P$-value \\
\hline \multicolumn{6}{|c|}{ Nutrient intake ${ }^{2}$} \\
\hline $\mathrm{DM}, \mathrm{kg} / \mathrm{d}$ & $8.84^{c}$ & $8.30^{\mathrm{b}}$ & $7.89^{\mathrm{a}}$ & 0.016 & $<0.01$ \\
\hline $\mathrm{CP}, \mathrm{kg} / \mathrm{d}$ & $1.14^{\mathrm{b}}$ & $1.03^{a}$ & $1.04^{\mathrm{a}}$ & 0.002 & $<0.01$ \\
\hline $\mathrm{ADF}, \mathrm{kg} / \mathrm{d}$ & $1.81^{\mathrm{c}}$ & $1.49^{\mathrm{b}}$ & $1.02^{\mathrm{a}}$ & 0.005 & $<0.01$ \\
\hline $\mathrm{NDF}, \mathrm{kg} / \mathrm{d}$ & $3.02^{c}$ & $2.49^{\mathrm{b}}$ & $1.83^{\mathrm{a}}$ & 0.007 & $<0.01$ \\
\hline $\mathrm{NFC}, \mathrm{kg} / \mathrm{d}$ & $4.25^{\mathrm{a}}$ & $4.42^{\mathrm{b}}$ & $4.61^{\mathrm{c}}$ & 0.008 & $<0.01$ \\
\hline $\mathrm{Ca}, \mathrm{g} / \mathrm{d}$ & $33.60^{c}$ & $30.29^{b}$ & $28.39^{a}$ & 0.062 & $<0.01$ \\
\hline$P, g / d$ & $26.53^{c}$ & $23.03^{a}$ & $23.65^{b}$ & 0.045 & $<0.01$ \\
\hline $\mathrm{Mg}, \mathrm{g} / \mathrm{d}$ & $17.69^{a}$ & $18.26^{\mathrm{b}}$ & $17.94^{\mathrm{a}}$ & 0.034 & $<0.01$ \\
\hline $\mathrm{K}, \mathrm{g} / \mathrm{d}$ & $117.64^{\mathrm{a}}$ & $92.96^{\mathrm{b}}$ & $80.43^{a}$ & 0.237 & $<0.01$ \\
\hline \multicolumn{6}{|l|}{ Energy intake } \\
\hline TDN, $\mathrm{kg} / \mathrm{d}^{3}$ & $6.38^{\mathrm{b}}$ & $6.24^{\mathrm{a}}$ & $6.20^{\mathrm{a}}$ & 0.012 & $<0.01$ \\
\hline ME, Mcal $/ d^{4}$ & $23.23^{\mathrm{b}}$ & $22.54^{\mathrm{a}}$ & $22.41^{\mathrm{a}}$ & 0.042 & $<0.01$ \\
\hline
\end{tabular}

a,b,c Means in the same row with different superscripts differ $(P<0.05)$.

${ }^{1} \mathrm{HC}=$ Heifers fed $60 \%$ concentrate diets; $\mathrm{MC}=40 \%$ concentrate diets; $\mathrm{LC}=$ $20 \%$ concentrate diets.

${ }^{2} n=6$ composite samples representing 42 samples per treatment taken daily throughout the collection periods.

${ }^{3}$ Total digestible nutrients (calculated from ingredients).

${ }^{4}$ Estimated: metabolizable energy $(\mathrm{ME})=\mathrm{TDN} \times 0.04409 \times 0.82$ (Lammers and Heinrichs, 2000).

\subsection{Rumen fluid and content samples}

Rumen contents were sampled on days 18 and 32 of each period at $-2,-1,0,1,2,4,6,8,10,12$, and 24 h relative to the $1000 \mathrm{~h}$ feeding. Rumen contents were strained through 4 layers of cheesecloth, and strained fluid was collected. Rumen fluid ( $15 \mathrm{ml}$ ) was preserved into $3 \mathrm{ml}$ of $25 \%$ metaphosphoric acid and $3 \mathrm{ml}$ of $0.6 \%$ 2-ethyl butyric acid (internal standard), and stored at $-20{ }^{\circ} \mathrm{C}$ until VFA and ammonia- $\mathrm{N}\left(\mathrm{NH}_{3}-\mathrm{N}\right)$ analyses (Moody et al., 2007). Ruminal pH was immediately recorded with a glass electrode $\mathrm{pH}$ Meter (Corning M90, Corning Inc., NY, USA). Whole rumen evacuation was completed $5 \mathrm{~h}$ post feeding on days 21 and 35 by manual removal. Total rumen contents were weighed, a representative sample taken, and immediately returned to the respective animals. Samples were dried $\left(102{ }^{\circ} \mathrm{C}\right)$ to determine mass of rumen contents and rumen liquid volume. The DM turnover was calculated from the dry rumen mass divided by the DM intake (Moody et al., 2007).

\subsection{In situ dry matter digestibility}

In situ digestibility was determined on days 14 to 17 and 28 to 31 of the treatment period, using LC and HC ground samples (TMR) in heifers fed both LC and HC diets. The MC diet (50\% HC: $50 \%$ LC TMR) was also measured for in situ digestibility as a standard in all heifers. The standard (MC) was used due to its similar CP percentage relative to the other two diets (in comparison to corn silage or alfalfa hay; Table 1). In situ samples were initially ground through a 2-mm screen using a Wiley Mill (Arthur H. Thomas, Philadelphia, PA, USA). Then, $10-\times 20-\mathrm{cm}$ ANKOM bags (pore size of $50 \pm 15 \mu \mathrm{m}$; ANKOM Technology Corporation, Fairport, NY, USA) were filled with approximately $8 \mathrm{~g}$ of feed and attached to cords with weights and snaps to enable attachment to the outer rim of the cannula. Bags were placed in $39^{\circ} \mathrm{C}$ distilled water for 15 -min prior to insertion into the rumen, and incubated in heifers for 72, 48, 36, 24, 16, 12, 8, 4, 2, 1 and $0 \mathrm{~h}$ (sequentially addition) before being removed all at once $2 \mathrm{~h}$ post feeding (at $1200 \mathrm{~h}$ ). Bags were separated, rinsed manually with tap water (including the 0 -h bag), and put through the 2-min rinse cycle of a washing machine 3 times. Bags were then rolled, dried in a forced air oven $\left(55^{\circ} \mathrm{C}\right)$ for 4 days, and weighed to determine DM digestibility (DMD).

\subsection{Statistical analysis}

All statistical analysis was conducted using the PROC MIXED procedure of SAS (2006). Least square means and standard errors were determined using the LSMEANS for nutrient content of treatments, and differences of least square means were determined using the PDIFF statement. Sources of variation included design effects of period and fixed treatment effects of $\mathrm{F}: \mathrm{C}$ and $\mathrm{YC}$ addition. Heifer was included as a random effect. All dependent variables, with the exception of ruminal repeated measurements, were analyzed as a $3 \times 3$ Latin square design with the following model:

$Y_{i j \mathrm{kd}}=\mu+a_{i}+b_{j}+y_{k}+p_{d}+y a_{i k}+e_{i j k l}$

Where $Y_{i j k d}$ is the dependent response variable from receiving $i$ th treatment ( $i=1$ to 3 ) on the $j$ th heifer $(j=1$ to 
Table 3

Rumen fermentation parameters of Holstein heifers fed high concentrate (HC), medium concentrate (MC), and low concentrate (LC) rations with yeast culture supplementation (YC) or control (CC).

\begin{tabular}{|c|c|c|c|c|c|c|c|c|c|}
\hline & \multicolumn{3}{|c|}{ Diet $\left(\mathrm{F}: \mathrm{C}^{1}\right.$ ratio) } & \multirow{3}{*}{$\mathrm{SE}^{2}$} & \multicolumn{2}{|l|}{ Yeast } & \multirow{3}{*}{$\mathrm{SE}^{2}$} & \multirow{3}{*}{$\frac{\text { Significance }}{F^{3}}$} & \multirow{3}{*}{$\mathrm{YC}^{4}$} \\
\hline & $\overline{\mathrm{LC}}$ & $\mathrm{MC}$ & $\mathrm{HC}$ & & $\overline{\mathrm{CC}}$ & YC & & & \\
\hline & $80: 20$ & $60: 40$ & $40: 60$ & & & & & & \\
\hline \multicolumn{10}{|l|}{ Daily pH } \\
\hline Mean & 6.07 & 6.07 & 6.07 & 0.12 & 6.08 & 6.06 & 0.07 & 0.96 & 0.71 \\
\hline Max & 7.01 & 7.01 & 7.09 & 0.06 & 7.01 & 7.08 & 0.05 & 0.38 & 0.27 \\
\hline Min & 5.29 & 5.43 & 5.39 & 0.24 & 5.36 & 5.38 & 0.14 & 0.78 & 0.86 \\
\hline Total VFA (mM) & 120.69 & 118.79 & 116.82 & 7.28 & 113.87 & 123.66 & 4.45 & 0.81 & $<0.01$ \\
\hline \multicolumn{10}{|l|}{ Individual VFA, mol/100 mol } \\
\hline Acetate & $63.16^{\mathrm{a}}$ & $61.77^{\mathrm{ab}}$ & $59.29^{\mathrm{b}}$ & 0.91 & 60.98 & 61.83 & 0.7 & $0.04^{\mathrm{L}}$ & 0.38 \\
\hline Propionate & $18.25^{\mathrm{b}}$ & $18.14^{\mathrm{b}}$ & $21.45^{\mathrm{a}}$ & 0.74 & 19.19 & 19.37 & 0.61 & $0.01^{\mathrm{L}}$ & 0.84 \\
\hline Butyrate & 12.91 & 14.41 & 13.27 & 1.32 & 14.25 & 12.81 & 0.81 & 0.85 & 0.05 \\
\hline Valerate & 2.77 & 2.73 & 2.57 & 0.83 & 2.58 & 2.84 & 0.49 & 0.87 & 0.29 \\
\hline Isovalerate & 1.84 & 1.79 & 21.32 & 0.34 & 1.87 & 1.97 & 0.21 & 0.57 & 0.43 \\
\hline Isobutyrate & 1.09 & 1.17 & 1.28 & 0.17 & 1.14 & 1.22 & 0.10 & 0.47 & 0.13 \\
\hline Isoacids ${ }^{5}$ & 2.93 & 2.96 & 3.42 & 0.51 & 3.01 & 3.19 & 0.31 & 0.53 & 0.31 \\
\hline Acetate-to-propionate ratio & $3.47^{\mathrm{b}}$ & $3.44^{\mathrm{b}}$ & $2.79^{\mathrm{a}}$ & 0.13 & 3.23 & 3.24 & 0.11 & $<0.01^{\mathrm{L}}$ & 0.91 \\
\hline \multicolumn{10}{|l|}{$\mathrm{NH}_{3} \mathrm{~N}$} \\
\hline Mean mg/dl & 4.72 & 4.51 & 4.47 & 0.68 & 5.73 & 3.41 & 0.75 & 0.81 & $<0.01$ \\
\hline Wet rumen mass, $\mathrm{kg}^{6}$ & $55.80^{\mathrm{b}}$ & $48.44^{\mathrm{b}}$ & $43.07^{\mathrm{a}}$ & 2.41 & 48.89 & 49.32 & 1.45 & $0.02^{\mathrm{L}}$ & 0.61 \\
\hline Rumen liquid volume, $1^{7}$ & $48.05^{\mathrm{a}}$ & $42.34^{b}$ & $37.22^{c}$ & 2.21 & 41.13 & 39.98 & 1.56 & $0.03^{\mathrm{L}}$ & 0.72 \\
\hline Rumen liquid volume, \% & 86.11 & 87.42 & 86.42 & 2.52 & 86.24 & 86.43 & 3.44 & 0.83 & 0.87 \\
\hline Dry rumen mass, $\mathrm{kg}^{7}$ & $7.82^{\mathrm{b}}$ & $7.10^{\mathrm{b}}$ & $6.15^{\mathrm{a}}$ & 0.28 & 7.02 & 7.03 & 0.16 & $0.01^{\mathrm{L}}$ & 0.97 \\
\hline DM turnover rate, per $\mathrm{d}^{8}$ & $0.88^{\mathrm{b}}$ & $0.81^{\mathrm{a}}$ & $0.78^{\mathrm{a}}$ & 0.01 & 0.82 & 0.82 & 0.01 & $<0.01^{\mathrm{L}}$ & 0.91 \\
\hline In situ DM digestion rate, $\% / \mathrm{h}$ & & & & & & & & & \\
\hline Standard (MC) ${ }^{9}$ & 3.73 & 4.05 & 3.57 & 0.29 & 3.83 & 3.78 & 0.18 & 0.66 & 0.87 \\
\hline
\end{tabular}

a,b,c Means in the same row with different superscripts differ $(P<0.05)$.

${ }^{1}$ Forage-to-concentrate ratio.

${ }^{2}$ Standard error of the main effects of diet and YC.

${ }^{3}$ Main effect of forage-to-concentrate ratio.

${ }^{4}$ Main effect of YC

${ }^{5}$ Isobutyrate + Isovalerate.

${ }^{6}$ Determined by whole rumen evacuation.

${ }^{7}$ Samples were dried $\left(102{ }^{\circ} \mathrm{C}\right)$ to determine mass of rumen contents and rumen liquid volume.

${ }^{8} \mathrm{DM}$ turnover calculated from the dry rumen mass divided by the DM intake.

${ }^{9} 50 \%$ HC: $50 \%$ LC TMR.

${ }^{\mathrm{L}}$ Linear effect from increasing proportion of concentrate in the diet.

3 ), with or without the $k$ th YC addition ( $k=1$ to 2 ) at the $d$ th period ( 1 to 3 ); $\mu$ is the overall mean; $a_{i}$ is the fixed effect of treatment; $b_{j}$ is the random effect of heifer; $y_{k}$ is the fixed effect of YC (subperiod); $p_{d}$ is the design effect of period; $y a_{i k}$ is the $\mathrm{YC} \times$ diet interaction; and $e_{i j k}$ is the residual error.

Because of unequally spaced rumen samples, mean daily $\mathrm{pH}$ of rumen fluid, $\mathrm{NH}_{3}-\mathrm{N}$ concentrations, and molar concentrations and proportions of VFA were determined by calculating the area under the response curve according to the trapezoidal rule (Shipley and Clark, 1972). All denominator degrees of freedom for $F$-tests were calculated according to Kenward and Roger (1997). Repeated measurements were performed for ruminal parameters such as $\mathrm{NH}_{3}-\mathrm{N}$, VFA and $\mathrm{pH}$, and the same model was used except that hour was added and the interaction with diet and YC was included. One of 5 model structures was used depending on the finite-sample corrected Akaike's information criterion value for data that best fit the model. The covariance structures were compound symmetry, heterogeneous compound symmetry, unstructured, autoregressive, and antedependence (Littell et al., 1998; Wang and Goonewardene, 2004). For each variable, the type of structure was chosen accordingly by using the smallest Akaike's information criterion value. Residual variances were assumed to be normally distributed, and all data are presented as least squares means obtained through the LSMEANS statement. Mean separations were determined using the PDIFF statement in PROC MIXED.

Because there were no significant $(P>0.05)$ interactions between diet and YC, only the main effect of YC and the effect of increasing the dietary concentrate are reported. In situ data were fit to the model of Orskov and McDonald (1979) for each MC TMR within heifer within period curve, with coefficients estimated in the NLIN procedure of SAS (2006), using the Marquardt compromise as the iterative method. Least squares means, standard errors, and statistical tests were then calculated by using the statistical procedures described above, with the coefficients derived from the NLIN procedure serving as the observed values. Treatment effects were considered significant when $P<0.05$ and trends were indicated by $P<0.10$.

\section{Results and discussion}

\subsection{Nutrient composition}

Most of the components of the rations differed between treatments as planned (Table 1). The objective of this experiment was to evaluate effect of YC on the rumen 
fermentation of different $\mathrm{F}: \mathrm{C}$ diets. It is known that $\mathrm{HC}$ diets differ significantly from LC diets fed normally to dairy heifers, especially in the fibrous and non fibrous content of the diet (Moody et al., 2007). In this experiment NDF and ADF decreased as concentrate percent increased in the diets. The opposite happened with the NFC fraction of the diets. The overall protein content of the diets was similar to their formulated value of $13 \% \mathrm{CP}$. The ME content of MC and $\mathrm{HC}$ was increased to compensate for the decrease in DMI needed (Hoffman et al., 2007) to attain a similar growth of $800 \mathrm{~g} / \mathrm{d}$ (NRC, 2001).

Nutrient and energy intakes of heifers fed the experimental diets are presented in Table 2. Dry matter intake decreased from LC to MC and HC diets as a direct result of higher energy density of the higher concentrate diets; hence, heifers being fed these energy dense diets consumed less DM per day to meet the necessary ME to achieve $800 \mathrm{~g} / \mathrm{d}$ ADG according to NRC (2001). There were differences in the total amount of metabolizable energy consumed per day between LC, MC and HC diets (23.23, 22.54, and $22.41 \pm 0.042 \mathrm{Mcal} / \mathrm{d}$ respectively). This difference has been attributed to the fact that HC diets have higher energy retention ability in comparison to diets with lower concentrate levels (Reynolds et al., 1991). Thereby, net energy for maintenance and gain were similar but ME energy required to attain similar ADG increased as the level of concentrate decreased (Hoffman et al., 2007). Variation in the CP\% of the diets and the different
DM intake did not allow complete isonitrogenous intakes to be attained. Diets LC, MC, and HC provided 1.14, 1.03 and $1.04 \mathrm{~kg} / \mathrm{d}$ of CP intake, respectively; nevertheless, provided an adequate CP intake for a target ADG of $800 \mathrm{~g} / \mathrm{d}$ (NRC, 2001). Minerals such as calcium, phosphorus, and magnesium resulted in some differences among diets, due to the different intakes, but in all diets they were also within the mineral recommendations (NRC, 2001). Potassium increased as the percentage of forage increased in the diet because of the higher content of this mineral in corn silage.

\subsection{Ruminal $\mathrm{pH}$}

Mean rumen $\mathrm{pH}$ was not affected by increasing the proportion of concentrate in the diets. Minimum $\mathrm{pH}$ recorded among treatments was 5.29 (Table 3) and was never maintained for more than $4 \mathrm{~h}$ (Fig. 1a). These results concurred with Maekawa et al. (2002), where pH did not differ between 40,50 and $60 \%$ concentrate in rations fed to lactating dairy cows. Adaptation to HC diets seems to be an important part of feeding management in reducing their negative effect on $\mathrm{pH}$. Ha et al. (1983) found that buffers (limestone, $\mathrm{NaHCO}_{3}$, or inclusion of $10 \%$ alfalfa) had a superior effect on increasing ruminal $\mathrm{pH}$ during the adaptation phase than when animals were completely adapted to HC diets. Animals in the present study were adapted to their assigned diets for 10 days with increasing or decreasing proportion of

(a)

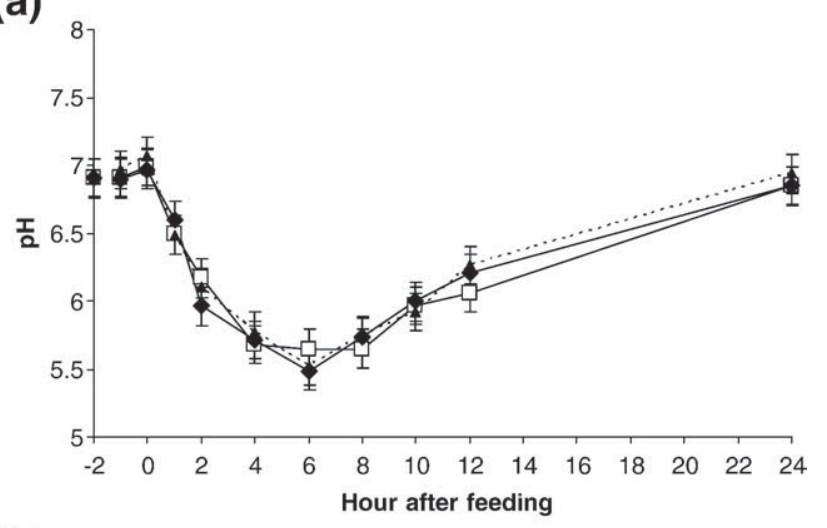

(b)

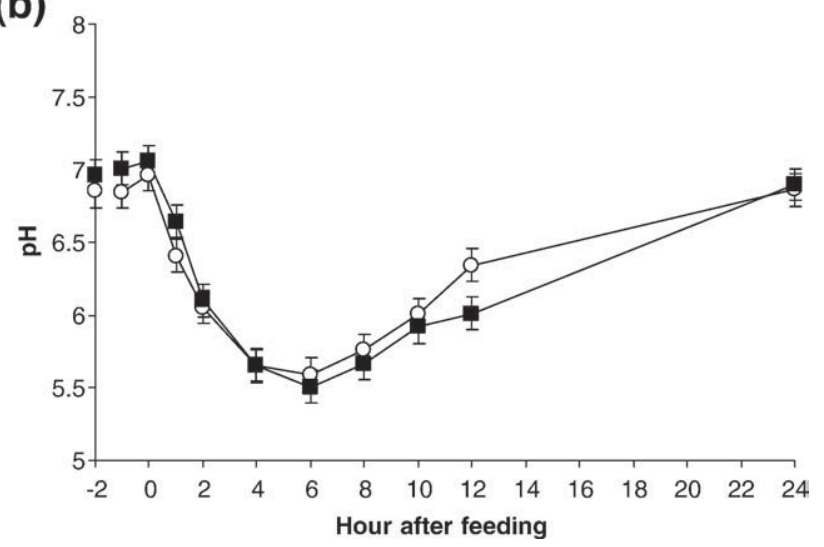

Fig. 1. Diurnal fluctuation of rumen pH of dairy heifers (a) fed diets containing low (LC; $\square$ ), medium (MC; $\$$ ), or high (HC; $\mathbf{\Delta}$ ) concentrate and (b) the main effect of the addition ( $\mathbf{\square})$ or not $(O)$ of yeast culture. 
(a)

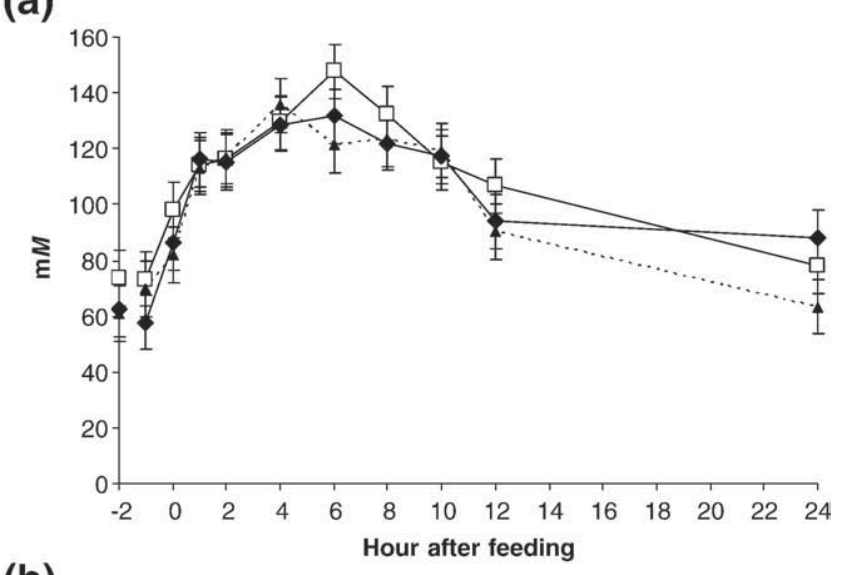

(b)

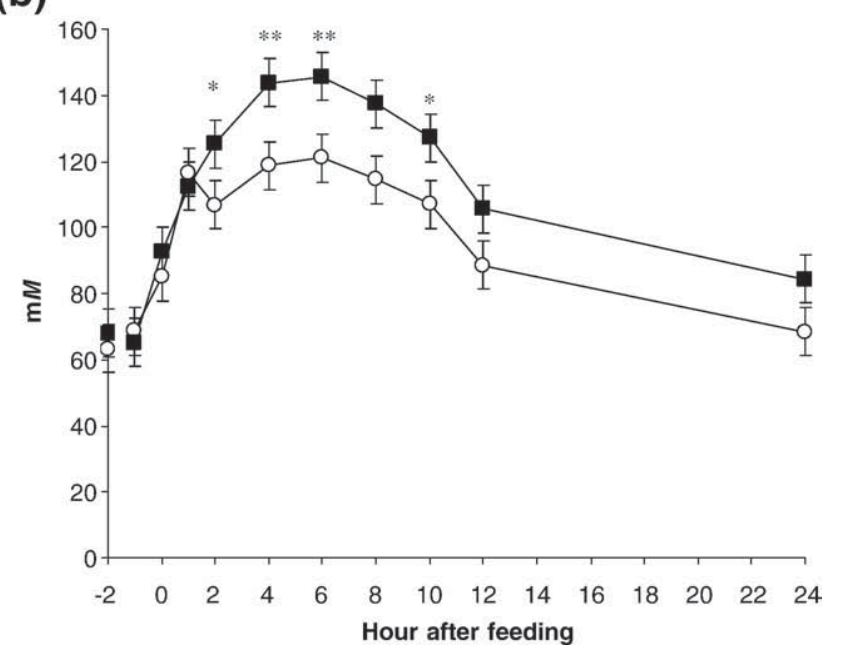

Fig. 2. Total volatile fatty acid (mM) concentrations the rumen of dairy heifers fed diets containing (a) low (LC; $\square$ ), medium (MC; $\bullet$ ), or high (HC; $\mathbf{\Delta}$ ) concentrate and (b) the main effect of the addition ( $\square$ ) or not ( $O$ ) of yeast culture. ( $\left.{ }^{* *} P<0.01 * P<0.05\right)$.

concentrate. The fact that HC diets were fed restrictively at a lower intake reduces the possibility of having lower $\mathrm{pH}$ in comparison to ad libitum feeding systems. Causes of lower $\mathrm{pH}$ can be attributed to increasing levels of starch fermentability rather than to differences in the F:C (Yang et al., 2001). Heifers were fed once daily, and the immediate decrease in ruminal

Table 4

Individual VFA concentration of Holstein heifers fed high concentrate (HC), medium concentrate (MC), and low concentrate (LC) rations with yeast culture supplementation (YC) or control (CC).

\begin{tabular}{|c|c|c|c|c|c|c|c|c|c|}
\hline & \multicolumn{3}{|c|}{ Diet $\left(\mathrm{F}: \mathrm{C}^{1}\right.$ ratio) } & \multirow{3}{*}{$\mathrm{SE}^{2}$} & \multicolumn{2}{|l|}{ Yeast } & \multirow{3}{*}{$\mathrm{SE}^{2}$} & \multicolumn{2}{|c|}{$P$ value } \\
\hline & \multirow{2}{*}{$\begin{array}{l}\mathrm{LC} \\
80: 20\end{array}$} & \multirow{2}{*}{$\frac{\mathrm{MC}}{60: 40}$} & \multirow{2}{*}{$\frac{\mathrm{HC}}{40: 60}$} & & \multirow[t]{2}{*}{$\overline{\mathrm{CC}}$} & \multirow[t]{2}{*}{$\mathrm{YY}$} & & \multirow[t]{2}{*}{$\overline{F^{3}}$} & \multirow[t]{2}{*}{$\mathrm{YC}^{4}$} \\
\hline & & & & & & & & & \\
\hline \multicolumn{10}{|c|}{ VFA concentration (mM) } \\
\hline Total VFA & 120.69 & 118.79 & 116.82 & 7.28 & 113.87 & 123.66 & 4.45 & 0.81 & $<0.01$ \\
\hline Acetate & $75.86^{a}$ & $73.45^{a}$ & $69.31^{\mathrm{b}}$ & 3.82 & 69.41 & 76.35 & 2.38 & 0.53 & $<0.01$ \\
\hline Propionate & $21.85^{b}$ & $21.71^{b}$ & $25.08^{a}$ & 1.03 & 21.81 & 23.95 & 0.68 & 0.18 & $<0.01$ \\
\hline Butyrate & 15.95 & 16.81 & 15.46 & 1.22 & 16.24 & 15.91 & 0.78 & 0.63 & 0.14 \\
\hline Valerate & 3.57 & 3.23 & 2.98 & 0.74 & 2.99 & 3.53 & 0.44 & 0.95 & 0.07 \\
\hline Isovalerate & 2.17 & 2.18 & 2.48 & 0.37 & 2.13 & 2.43 & 0.21 & 0.37 & $<0.01$ \\
\hline Isobutyrate & 1.29 & 1.42 & 1.53 & 0.16 & 1.33 & 1.51 & 0.09 & 0.46 & $<0.01$ \\
\hline Isoacids ${ }^{5}$ & 3.46 & 3.59 & 3.98 & 0.53 & 3.43 & 3.93 & 0.31 & 0.37 & $<0.01$ \\
\hline
\end{tabular}

a,b,c Means in the same row with different superscripts differ $(P<0.05)$.

${ }^{1}$ Forage-to-concentrate ratio.

${ }^{2}$ Standard error of the main effects of diet and YC.

${ }^{3}$ Main effect of YC.

${ }^{4}$ Main effect of forage-to-concentrate ratio.

${ }^{5}$ Isobutyrate + Isovalerate. 
pH post feeding (Fig. 1a) can be explained by the rapid consumption of readily available carbohydrates in a single meal.

Yeast culture has been shown to have a general pattern of increasing rumen $\mathrm{pH}$ when added to the diet of young and growing ruminants (Lascano and Heinrichs, 2007). In the present study no differences were found when YC was added to the treatment rations with respect to $\mathrm{pH}$ (Table 3). Fig. 1b presents the $\mathrm{pH}$ pattern of the addition of YC.

\subsection{Ruminal VFA concentration}

Variation of VFA throughout the day for LC, MC, and HC are presented in Table 3 and Fig. 2a. Total ruminal VFA concentrations (Table 3 ) and individual major VFA (acetate, propionate, and butyrate), valerate and isoacids (isobutyrate, isovalerate) concentrations did not differ between different $\mathrm{F}$ : $\mathrm{C}$ treatments (Table 4). Molar proportion of acetate in this experiment was higher in the LC diet and propionate in the HC diet (Table 3). Thus, there was a decrease in the ratio of acetate to propionate among dietary treatments ( $\mathrm{LC}$ to $\mathrm{HC}$ ). Whereas, acetate production is mainly due to the fermentation of structural carbohydrates by cellulolytic bacteria, propionate formation is mainly due to the fermentation of nonstructural carbohy- drates by amylolitic bacteria (Enjalbert et al., 1999). These changes in A:P show that there is a difference in the nature of rumen fermentation when different amounts of concentrate are being fed to the animal (Table 3 ). It is clear from these results that there was a shift of microbial population with different $\mathrm{F}: \mathrm{C}$ diets, yet fermentation was not compromised in any of the treatments.

Even though total VFA concentrations were similar among $\mathrm{F}: \mathrm{C}$ treatments, YC addition resulted in an increased VFA concentration (Fig. 2b) which could decrease ruminal $\mathrm{pH}$ if the VFAs were not absorbed (Yang et al., 2004). Yeast culture did not have an effect on acetate to propionate ratio due to proportional changes in acetate and propionate concentration with the YC addition (Table 3). These results are in agreement with Mutsvangwa et al. (1992) and indicate that there was an increase in rate of rumen fermentation and bacteria population when $\mathrm{YC}$ was added to the different $\mathrm{F}: \mathrm{C}$ diets, but not a change in the rumen fermentation pattern. In the same way, Callaway and Martin (1997) found increases in total VFA, propionate and acetate concentrations when YC filtrate ( 1 or $5 \%$ ) was added in-vitro to Selenomonas ruminantium cultures, and little effect when added to Megasphaera elsdenii cultures. Interestingly, in this experiment, isoacid molar proportions were similar when YC was added, but molar proportion of

\section{(a)}

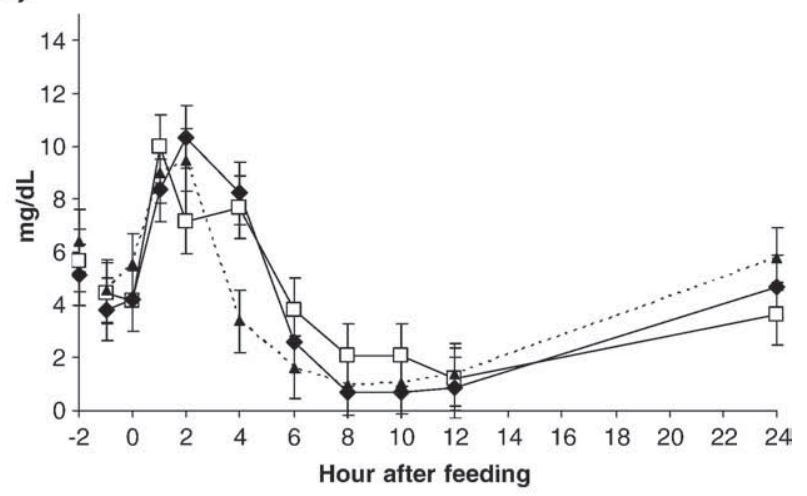

(b)

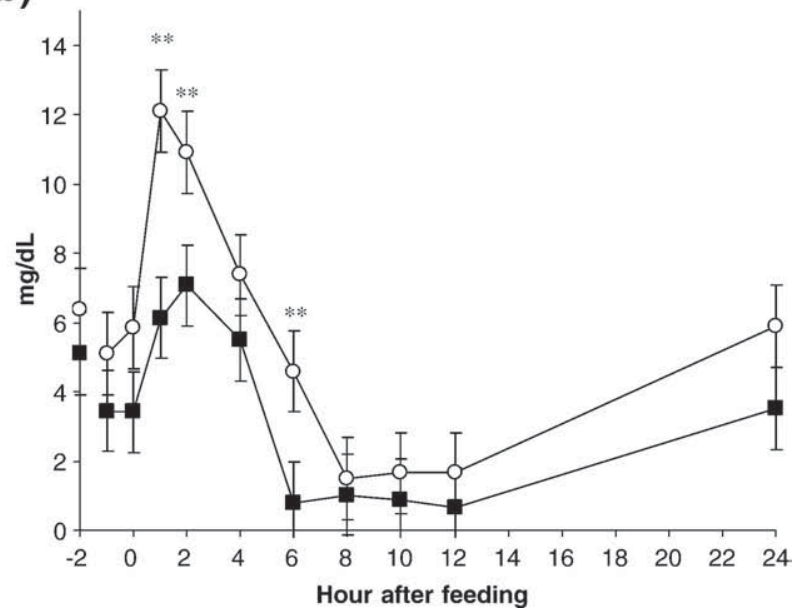

Fig. 3. Ammonia-N concentration ( $\mathrm{mg} / \mathrm{dl}$ ) in the rumen of dairy heifers fed diets containing (a) low (LC; $\square$ ), medium (MC; $\bullet$ ), or high (HC; $\mathbf{\Delta}$ ) concentrate and (b) the main effect of the addition $(\mathbf{\square})$ or not $(O)$ of yeast culture. ( $* * P<0.01 * P<0.05)$. 
butyrate decreased with the addition of YC. Similarly, butyrate proportions have decreased when glucose has been used as a substrate (Hino et al., 1994), and the opposite has happened when lactate has been used as the carbon source in continuous culture of M. elsdenii (Soto-Cruz et al., 2001). However, and in agreement with the results found in this experiment, butyrate concentration was not different when YC filtrate was added to M. elsdenii cultures (Callaway and Martin, 1997). All together, these results suggest that substrates or diets influenced the growth of different species of rumen microbes that are the responsible for the VFA production and pattern when YC is being used.

Published reports of the effect of YC on VFA concentrations are variable. A lack of response to supplemental YC has been attributed to low concentrate diets, low forage quality, or low feed intake (Olson et al., 1994); consequently, the variable responses in VFA production and patterns when YC has been used can be credited to dietary effects on microbial populations and numbers in the rumen (Wallace, 1996).

\subsection{Ruminal ammonia}

Ammonia concentrations were not different among $\mathrm{F}: \mathrm{C}$ variations (Table 3 ), and there were periods where concentrations were lower than $2 \mathrm{mg} / \mathrm{dl}$ (Fig. 3a), which was the minimal $\mathrm{NH}_{3}-\mathrm{N}$ concentration recommended by Satter and Slyter (1974) for microbial growth in continuous culture. Considering that heifers were fed once a day, sources of ammonia were being exhausted by bacterial activity, enhancing microbial growth, but not compromising it. An indicator of this is the higher VFA concentrations (Fig. 2a) when $\mathrm{NH}_{3}-\mathrm{N}$ concentrations were the lowest (Fig. 3a).

Ammonia is the main source of $\mathrm{N}$ for microbial protein synthesis (Bach et al., 2005) and bacteria can grow with $\mathrm{NH}_{3}-$ $\mathrm{N}$ as the sole $\mathrm{N}$ source (Virtanen, 1966). Rumen concentrations of $\mathrm{NH}_{3}-\mathrm{N}$ were significantly reduced by YC (Table 3 ). These data suggest that $\mathrm{NH}_{3}-\mathrm{N}$ concentrations may not be the limiting factor for microbial growth. But alternatively, this effect may be related to higher concentrations of cellulolytic and total bacteria (Harrison et al., 1988; Dawson et al., 1990; Williams et al., 1991), and not due to a decrease in proteolytic, amylolitic or deaminative activity of rumen microorganisms (Newbold et al., 1995; El Hassan et al., 1996). Research indicates that yeast additives either stimulate $\mathrm{NH}_{3}-\mathrm{N}$ uptake by bacteria, which allows better growth of these species in the rumen, or they stimulate the growth of cellulolytic bacteria, which could use more $\mathrm{NH}_{3}-\mathrm{N}$ to synthesize cellular nitrogenous components (Chaucheyras-Durand and Fonty, 2001). Even though, VFA molar proportions were similar without or with YC addition, the increase in VFA concentrations (Table 4) in this experiment indicates enhanced microbial activity in terms of fermentation and agrees with previous findings regarding total and cellulolytic bacteria numbers (Weidmeier et al., 1987; Dawson et al., 1990). It is noteworthy that YC has shown to have maximum stimulatory effects for 2 to $4 \mathrm{~h}$ with decreasing activity up to $12 \mathrm{~h}$ (Koul et al., 1998), indicating a necessity for frequent addition of YC to optimize effectiveness. Since yeasts are facultative aerobes and cannot easily survive in an anaerobic rumen environment; they have to be supplied continuously to maintain minimum effective concentration $\left(1 \times 10^{5} \mathrm{CFU} / \mathrm{g}\right.$ rumen contents; Jouany, 2006). The current experiment is in agreement with the observations made by Koul et al. (1998) and Jouany (2006); in fact, YC effects seemed to decrease several hours after feeding (Fig. 3b). Furthermore, in every period where YC was not supplemented to the diet, rumen $\mathrm{NH}_{3}-\mathrm{N}$ concentrations increased (Table 3).

\subsection{Isoacids}

It is well known that production of isoacids by microbes is related to potential release of amino acids (AA) and deamination from proteins in the rumen, and that this occurs when optimal rumen degradable proteins are consumed (Armentano et al., 1993; Yang et al., 2004). In the rumen, cellulolytic bacteria primarily use $\mathrm{NH}_{3}-\mathrm{N}$ while amylolytic bacteria prefer to use AA as they have a proteolytic activity. The first stage of ruminal nutrient degradation involves the attachment of bacteria to feed particles. Feed particles are attached by 70 to $80 \%$ of ruminal bacteria (Miron et al., 2001) and about $50 \%$ of these bacteria have proteolytic activity (Bach et al., 2005). The end products of this process are peptides and AA. These AA and peptides can be incorporated into microbial protein or further deaminated to VFA if energy is needed by ruminal bacteria (Bach et al., 2005). El Hassan et al. (1996) found increased content of protein in the rumen when YC was added and this could be related to the increased incorporation of $\mathrm{NH}_{3}-\mathrm{N}$ into microbial protein. The addition of YC can stimulate amylolitic bacteria that would use preferably true degradable protein, and would result in an increase in the concentration of ruminal isoacids and valerate (Dawson et al., 1990). Isoacid concentrations in the present experiment were increased with the addition of YC (Table 4). Considering that fiber digestion can be depressed when an insufficient amount of protein is supplied to the animal. It has to be taken into consideration that protein is of higher value than $\mathrm{NH}_{3}-\mathrm{N}$ for fiber digestion to be maintained (Hoover, 1986). Most cellulolytic bacteria need isoacids derived from protein deamination to enhance their growth and fiber digestion (Yang, 2002). Stimulatory effects in fiber digestion, such as supply of AA for the enhanced growth of cellulolytic bacteria, have been demonstrated with isoacids addition (Gorosito et al., 1985). Results from this experiment indicate that $\mathrm{NH}_{3}-\mathrm{N}$ concentration was lower (Fig. $3 \mathrm{~b}$ ) and the isoacids concentration was higher with YC addition. This could be one way YC favors cellulolytic bacteria activity and stimulates its growth (Hoover, 1986; Harrison et al., 1988), and fiber digestion in the rumen.

\subsection{Rumen contents and volume}

As the inclusion of concentrate increased, DM turnover was lower (Table 3). Moody et al. (2007) attributed this result to restricted intake and to the higher amount of DM intake required to attain the ME necessary to achieve ADG of $800 \mathrm{~g} / \mathrm{d}$ for higher forage diets. It has been shown that when higher amounts of fiber are being fed to animals from forages, particle size is greater, and the time that these particles stay in the rumen is longer due to a reduction in the passage rate of fiber (Jung and Allen, 1995). Due to the higher DM intake of LC heifers in comparison to MC and HC, wet and dry rumen mass decreased as the proportion of concentrate included in the 
diet increased (Table 3). This is opposite to what Maekawa et al. (2002) found when feeding 60:40, 50:50, and 40:60 F:C ad libitum to lactating cows; this difference could be explained by the lower DMI of cows eating the 60:40 diet in this study because of rumen fill. While in the present study, heifers fed restrictively the LC $(60: 40 \mathrm{~F}: \mathrm{C})$ diet had the highest DM intake (Table 2). Important to notice is that in both studies the \% of liquid volume of the three different $\mathrm{F}: \mathrm{C}$ diets was around 85 , and rumen liquid volume (1) was proportionally equal among diets (Table 3 ). These results suggest that rumen volume may have a positive association with DM intake when diets are being restricted. The inclusion of YC did not have any effect on the wet or dry rumen contents or on DM turnover.

\subsection{In situ dry matter digestibility}

The rate of in situ DMD of MC (standard control) was not different among dietary treatments (Table 3 ). Moody et al. (2007) used corn silage as a control and found no differences in the rate of in-situ DMD and suggested that this effect was indicative of small differences in rumen environments between low or high concentrate diets. In this experiment the MC diet was used as a control and no differences were found among treatments nor with the addition or not of YC.

\section{Conclusions}

Feeding $\mathrm{HC}$ diets at restricted intakes did not have any differences on the concentration of rumen fermentation parameters. The concentrations of these fermentation parameters were similar between LC, MC, and HC diets regardless of the difference in nutrient composition of the experimental diets. Concentration of total VFA were similar among the different F: $C$ treatments. But molar proportions of acetate and propionate increased and decreased (respectively) linearly when higher levels of concentrate were added to the diets. This resulted in a decrease in the A:P as more concentrate was added to the diet. Ruminal pH was not affected by F:C or YC supplementation. Total, wet and dry rumen contents, and DM turnover were different between all $\mathrm{F}: \mathrm{C}$ treatments with no YC effect over these parameters, showing that rumen manipulation can be achieved with $\mathrm{F}: \mathrm{C}$ having no major effect on fermentation rate. HC diets changed rumen fermentation towards a more propionic pattern.

There was an increase in total VFA concentrations with YC addition in all diets, but molar proportions of individual VFA (acetate, propionate), valerate and isoacids (isobutyrate, and isovalerate) were not different, suggesting an increase in the fermentation rate when YC was added but not a change in the fermentation pattern. These results are concurrent with the decreased $\mathrm{NH}_{3}-\mathrm{N}$ concentration in all treatments when $\mathrm{YC}$ was added, suggesting an increase in rumen microbial activity. YC enhanced the output of fermentation products at the rumen level.

In summary, these results show that dairy heifers may be fed restricted $\mathrm{HC}$ diets with no impact on rumen $\mathrm{pH}$ or ruminal ammonia concentration, decreasing the $\mathrm{A}: \mathrm{P}$ and achieve similar rumen fermentation rates as LC diets. YC addition is beneficial to improve the fermentation rate in corn silage based diets across a range of $\mathrm{F}$ : C, suggesting an increased microbial activity and growth.

\section{Acknowledgements}

The authors acknowledge the assistance of Maria Long and Carrie Nelson with this research as well as the financial support and yeast supplied by Alltech Inc.

\section{References}

AOAC, 1990. Official Methods of Analysis, 15th ed. Association of Official Analytical Chemists, Arlington, VA.

Arambel, M.J., Kent, B.A., 1990. Effect of yeast culture on nutrient digestibility and milk yield response in early- to mid lactation dairy cows. J. Dairy Sci. 73, 1560-1563.

Armentano, L.E., Bertics, S.J., Riesterer, J., 1993. Lack of response to addition of degradable protein to a low protein diet fed to midlactation dairy cows. J. Dairy Sci. 76, 3755-3762.

Bach, A., Calsamiglia, S., Stern, M.D., 2005. Nitrogen metabolism in the rumen. J. Dairy Sci. 88 (E. Suppl.), E9-E21.

Callaway, E.S., Martin, S.A., 1997. Effects of Saccharomyces cerevisiae culture on ruminal bacteria that utilize lactate and digest cellulose. J. Dairy Sci. 80, 2035-2044.

Carro, M.D., Rohr, K., Lebzien, P., 1992. Influence of yeast culture on the in vitro fermentation (Rusitec) of diets containing variable portions of concentrates. Anim. Feed Sci. Technol. 37, 209-220.

Chaucheyras-Durand, F., Fonty, G., 2001. Establishment of cellulolytic bacteria and development of fermentative activities in the rumen of gnotobiotically-reared lambs receiving the microbial additive Saccharomyces cerevisiae CNCM I-1077. Reprod. Nutr. Develop. 41, 57-68.

Dawson, K.A., Newman, K.E., Boling, J.A., 1990. Effects of microbial supplements containing yeast and lactobacilli on roughage-fed ruminal microbial activities. J. Anim Sci. 62, 43-48.

El Hassan, S.M., Newbold, C.J., Edwards, I.E., Topps, J.H., Wallace, R.J., 1996. Effect of yeast culture on rumen fermentation, microbial protein flow from the rumen and live-weight gain in bulls given high cereal diets. Anim. Sci. 62, 43-48.

Enjalbert, F., Garret, J.E., Moncoulon, R., Bayourthe, C., Chicoteau, P., 1999. Effect of yeast culture (Saccharomyces cerevisiae) on ruminal digestion in non-lactating dairy cows. Anim. Feed Sci. Technol. 76, 195-206.

Gerrard, D.E., Grant, A.L., 2003. Principles of Animal Growth and Development. Kendall/Hunt Publishing Co., Dubuque, IA.

Gorosito, A.R., Russell, J.B., Van Soest, P.J., 1985. Effect of carbon-4 and carbon5 volatile fatty acids on digestion of plant cell wall in vitro. J. Dairy Sci. 68 , 840-847.

Ha, J.K., Emerick, R.J., Embry, L.B., 1983. In vitro effect of pH variations on rumen fermentation, and in vivo effects of buffers in lambs before and after adaptation to high concentrate diets. J. Anim Sci. 56, 698-706.

Harrison, G.A., Hemken, R.W., Dawson, K.A., 1988. Influence of addition of yeast culture supplement to diets of lactating cows on ruminal fermentation and microbial populations. J. Dairy Sci. 71, 2967-2975.

Hino, T., Kimiomi, S., Maruyama, T., 1994. Substrate preference in a strain of Megasphaera elsdenii, a ruminal bacterium, and its implications in propionate production and growth competition. Appl. Environ. Microbiol. 60, 1827-1831.

Hoffman, P.C., Simson, C.R., Wattiaux, M., 2007. Limit feeding of gravid Holstein heifers: effect on growth, manure nutrient excretion, and subsequent early lactation performance. J. Dairy Sci. 90, 946-954.

Hoover, W.H., 1986. Chemical factors involved in ruminal fiber digestion. J. Dairy Sci. 69, 2755-2766.

Jouany, J.P., 2006. Optimizing rumen functions in the close-up transition period and early lactation to drive dry matter intake and energy balance in cows. Anim. Reprod. Sci. 96, 250-264.

Jung, H.G., Allen, M.S., 1995. Characteristics of plant cell walls affecting intake and digestibility of forages by ruminants. J. Anim. Sci. 73, 2774-2790.

Kenward, M.G., Roger, J.H., 1997. Small sample inference for fixed effects from restricted maximum likelihood. Biometrics 53, 983-997.

Koul, V., Kumar, U., Sareen, V.K., Singh, S., 1998. Mode of action of yeast culture (YEA-SACC 1026) for stimulation of rumen fermentation in buffalo calves. J. Sci. Food Agric. 77, 407-413.

Lascano, G.J., Heinrichs, A.J., 2007. Yeast culture (Saccharomyces cerevisiae) supplementation in growing animals in the dairy industry. CAB Reviews: Perspectives in Agriculture, Veterinary Science, Nutrition and Natural Resources, vol. 2, 049.

Lammers, B.P., Heinrichs, A.J., 2000. The response of altering the ratio of dietary protein to energy on growth, feed efficiency, and mammary development in rapidly growing prepubertal heifers. J. Dairy Sci. 83, 977-983.

Littell, R.C., Henry, P.R., Ammerman, C.B., 1998. Statistical analysis of repeated measures data using SAS procedures. J. Anim. Sci. 76, 1216-1231. 
Loerch, S.C., 1990. Effects of feeding growing cattle high-concentrate diets at a restricted intake on feedlot performance. J. Anim Sci. 68, 3086-3095.

Maekawa, M., Beauchemin, K.A., Christensen, D.A., 2002. Effect of concentrate level and feeding management on chewing activities, saliva production, and ruminal pH of lactating dairy cows. J. Dairy Sci. 85, 1165-1175.

Miron, J., Ben-Ghedalia, D., Morrison, M., 2001. Invited review: adhesion mechanisms of rumen cellulolytic bacteria. J Dairy Sci. 84, 1294-1309.

Moody, M.L., Zanton, G.I., Daubert, J.M., Heinrichs, A.J., 2007. Nutrient utilization of differing forage-to-concentrate ratios by growing Holstein heifers. J. Dairy Sci. 90, 5580-5586.

Mutsvangwa, T., Edwards, I.E., Topps, J.H., Paterson, G.F.M., 1992. The effect of dietary inclusion of yeast culture (Yea-Sacc) on patterns of rumen fermentation, food intake and growth of intensively fed bulls. Anim. Prod. 55, 35-40.

Newbold, C.J., Wallace, R.J., Chen, X.B., McIntosh, F.M., 1995. Different strains of Saccharomyces cerevisiae differ in their effects on ruminal bacterial numbers in vitro and in sheep. J. Anim Sci. 73, 1811-1818.

NRC, 2001. The Nutrient Requirements of Dairy Cattle. Natl. Acad. Press, Washington, D.C.

Olson, K.C., Caton, J.S., Kirby, D.R., Norton, P.L., 1994. Influence of yeast culture supplementation and advancing season on steers grazing mixed-grass prairie in the northern Great Plains: II. ruminal fermentation, site of digestion, and microbial efficiency. J. Anim. Sci. 72, 2158-2170.

Orskov, E.R., McDonald, I., 1979. Estimation of protein degradability in the rumen from incubation measurements weighed according to rate of passage. J. Agric. Sci. (Camb.) 92, 499-503.

Pirlo, G., Miglior, F., Speroni, M., 2000. Effect of age at first calving on production traits and on difference between milk yield returns and rearing costs in Italian Holsteins. J. Dairy Sci. 83, 603-608.

Reynolds, C.K., Tyrrell, H.F., Reynolds, P.J., 1991. Effects of diet forage-toconcentrate ration and intake on energy metabolism in growing beef heifers: whole body energy and nitrogen balance and visceral heat production. J. Nutr. 121, 994-1003.

Robinson, P.H., Erasmus, L.J., 2007. Lactating dairy cow responses to yeast products. J. Dairy Sci. 90 (Suppl. 1) Abstr. 362.

SAS Institute, 2006. SAS User's Guide Statistics. Version 9.1. SAS Inst. Inc, Cary, NC.

Satter, L.D., Slyter, L.L., 1974. Effect of ammonia concentration on rumen microbial protein production in vitro. Br. J. Nutr. 32, 199-208.

Shipley, R.A., Clark, R.E., 1972. Tracer methods for in vivo kinetics. Academic Press, New York, NY
Soto-Cruz, O., Chávez-Rivera, R., Saucedo-Castañeda, G., 2001. Stimulation of the Megasphaera elsdenii butyrate production in continuous culture by a yeast additive. Braz. Arch. Biol. Technol. 44, 179-184.

Van Soest, P.J., Robertson, J.B., Lewis, B.A., 1991. Symposium: carbohydrate methodology, metabolism, and nutritional implications in dairy cattle. J. Dairy Sci. 74, 3583-3597.

Virtanen, A.I., 1966. Milk production of cows on protein-free feed. Science 53 1603-1614.

Wallace, R.J., 1996. The mode of action of yeast culture in modifying rumen fermentation. In: Lyons, T.P. Jacques, K.A. (Eds.), Biotechnology in the Feed Industry. Proc. of Alltech's 12th Ann. Symp. Nottingham Univ. Press, Nottingham, United Kingdom, pp. 217-232.

Wang, Z., Goonewardene, L.A., 2004. The use of mixed models in the analysis of animal experiments with repeated measures data. Can. J. Anim. Sci. 84 $1-11$.

Weidmeier, R.D., Arambel, M.J., Walters, J.L., 1987. Effect of yeast culture and Aspergillus oryzae fermentation extract on ruminal characteristics and nutrient digestibility. J. Dairy Sci. 70, 2063-2068.

Williams, P.E.V., Tait, C.A.G., Innes, G.M., Newbold, C.J., 1991. Effects of the inclusion of yeast culture (Saccharomyces cerevisiae plus growth medium) in the diet of dairy cows on milk yield and forage degradation and fermentation patterns in the rumen of steers. J. Anim Sci. 69, 3016-3026

Yang, C.-M.J., 2002. Response of forage fiber degradation by ruminal microorganisms to branched-chain volatile fatty acids, amino acids, and dipeptides. J. Dairy Sci. 85, 1183-1190.

Yang, W.Z., Beauchemin, K.A., Rode, L.M., 2001. Effects of grain processing forage to concentrate ratio, and forage particle size on rumen $\mathrm{pH}$ and digestion by dairy cows. J. Dairy Sci. 84, 2203-2216.

Yang, W.Z., Beauchemin, K.A., Vedres, D.D., Ghorbani, G.R., Colombatto, D. Morgavi, D.P., 2004. Effects of direct-fed microbial supplementation on ruminal acidosis, digestibility, and bacterial protein synthesis in continuous culture. Anim. Feed Sci. Technol. 114, 179-193.

Zanton, G.I., Heinrichs, A.J., 2005. Meta-analysis to assess effect of prepubertal average daily gain of Holstein heifers on first-lactation production. J. Dairy Sci. 88, 3860-3867.

Zanton, G.I., Heinrichs, A.J., 2007. The effects of controlled feeding of a highforage or high-concentrate ration on heifer growth and first-lactation milk production. J. Dairy Sci. 90, 3388-3396. 